« Knowledge Integration and Network Formation »

Faculté des sciences économiques et de gestion Pôle européen de gestion et d'économie (PEGE) 61 avenue de la Forêt Noire F-67085 Strasbourg Cedex

Secrétariat du BETA Christine Demange Tél. : (33) 0390242069 Fax : (33) 0390242070 demange@cournot.u-strasbg.fr http://cournot.u-strasbg.fr/beta

\author{
$\underline{\text { Auteur }}$ \\ Müge OZMAN \\ Document de travail $\mathrm{n}^{\circ}$ 2006-06 \\ Müge OZMAN
}

Janvier 2006 


\title{
Knowledge Integration and Network Formation *
}

\author{
Müge Ozman \\ Bureau d' Economie Théorique et Appliquée (BETA) \\ 61 avenue de la Forêt Noire \\ 67085 Strasbourg France \\ Tél : +33 390242069 \\ Fax: +33 390242071 \\ e-mail: ozman@cournot.u-strasbg.fr
}

June 1, 2005

\begin{abstract}
In this paper, we highlight how inter-firm collaboration networks are influenced by the knowledge composition of goods in an industry. For this purpose, we carry out an agent based simulation study in which firms integrate their competencies under different knowledge base regimes. In this way networks form. The results reveal that, knowledge regime significantly influences the network structure, and interaction among firms is very intensive when the products are specialized but also have common knowledge among them.
\end{abstract}

\section{Introduction}

In recent decades, the intensity of horizontal and vertical relations among firms has increased to a large extent, especially in the case of knowledge intensive industries. The rapid innovations and increasing product complexity in these industries have not only raised the requirements for compatibility among product components, but have also been accompanied by richer technological opportunities. These developments prepared the grounds for intensive relations among firms, in the face of difficulties faced by a single firm to be self sufficient in serving a rapidly changing market. Mostly, interdependencies among products, compatibility requirements, specialization and collaboration accompany each other in these systems. Task complexity, combined with time pressure, makes coordination among firms more efficient than vertical hierarchies [1,2].

*I thank Robin Cowan for many helpful suggestions. 
In such an environment, knowledge has become a central factor in influencing industry dynamics. In most industries, firms need to pursue strategies that favour external relations, not only in subcontracting components but also to share knowledge and make use of knowledge spillovers. A major process that accompanies the inter-firm relations is the significant knowledge flow that takes place between the firms, which is usually considered to be an important engine for innovation. These knowledge spillovers are not only caused by formalized arrangements between firms, but may also be the result of informal communications, a concept which Allen [3] termed to be collective invention (see also [4]). The structure of networks among firms is inevitably influenced by the competencies needed in production and the architecture of these networks yield insights into effectiveness and efficiency with which knowledge is transferred, created and also the innovative performance of firms $[5,7]$.

There is a rich literature that addresses in a broad sense the relation between knowledge specific characteristics and networks. Among these, studies that focus on uncertainty and industry events $[8,10]$; complementarities in goods [11], similarities in knowledge bases $[12,13]$ the stage in the industry life cycle [14]; interdependence in products [15], system embeddedness and observability of knowledge [16]; hierarchical organization of knowledge base [17], characteristics of knowledge in terms of technological opportunities and tacitness [18] can be cited.

The question addressed in this paper is how the network structure responds to different knowledge base regimes. The approach that is used differs from previous studies in that a dynamic network approach is adopted Specifically, in the agent based simulation model, self interested actors who have competencies in different areas chose partners to integrate their knowledge and produce. Actors also learn from each other in this process, and networks form by the interactions among them. We analyse these networks and highlight the relation between patterns of interaction and knowledge base of the industry. We model the knowledge base using the concept of relatedness among products (similarity in their knowledge requirements) and the level of specialization of products. The results reveal that, interaction among actors is very intensive when the products are specialized but also have common knowledge among them.

The paper is organized as follows. In the first section, we explain the main model and present some preliminary analytical results. In the second section we present an agent based simulation study where self interested economic actors form networks to integrate their knowledge. We analyse the structure of resulting networks under different regimes of the knowledge base in the third section. Some discussions and concluding remarks follow in the last section. 


\section{The Model}

\subsection{General}

Let us consider a simple economy in which there are two producers, two goods and two knowledge types. Each of the goods require both types of knowledge in their production, though the intensity of use can be different. Specifically, we assume a Cobb-Douglas production function for each good, with two knowledge inputs and where $\gamma_{m j}$ measures the extent to which good $m$ is knowledge $j$ intensive (we assume constant returns to scale, so that $\gamma_{m 1}+\gamma_{m 2}=1$ for each good). To formalize, denote knowledge input by $k$, where $k_{i j}$ shows producer $i^{\prime} s$ knowledge endowment in area $j$. It follows that the amount of product $m$ that can be produced by $i$ is given by;

$$
y_{m}^{i}=\alpha \prod_{j=1,2} k_{i j}^{\gamma_{m j}} \quad \text { where } \quad \sum_{j} \gamma_{m j}=1
$$

where $\alpha$ is a production parameter. We assume that there are no competing uses for the knowledge, so that its opportunity cost is zero, and producers use all their knowledge in production. We also assume that demand is perfectly elastic so that profits increase monotonically with quantity. We take relative prices to be unity.

We assume that each of the producers is knowledgeable in both types, but is specialized in only one of them (i.e. knows one type of knowledge more than the other). Let us assume that producer 1 is expert in knowledge type 1 , and producer 2 is expert in knowledge type 2, so that $k_{11}>k_{12}$ and $k_{22}>k_{21}$. Single production means that a producer performs the production activity by him/herself alone, utilizing his/her own knowledge in both types. Accordingly, if production is to be maximised, he/she will produce that good which uses his expertise area more intensively. We assume that good 1 is knowledge 1 intensive, and good 2 is knowledge 2 intensive, so that $\gamma_{11}>\gamma_{12}$ and $\gamma_{22}>\gamma_{21}$ (Since we assume constant returns to scale, this implies that $\gamma_{11}>1 / 2$ and $\left.\gamma_{22}>1 / 2\right)$. Then, it is straightforward to show that in the single case, producer 1 produces good 1 , and producer 2 produces good 2. ${ }^{1}$

\subsection{Knowledge Integration}

Single production is only one of the options that the producer can chose. Otherwise, output can further be increased if both producers integrate their knowledge, produce both goods together and share the final output. In making this choice, we assume that the producer simply makes a comparison between the two cases (single or joint), and selects the one that yields more output for him. For pairwise production to be realized, both producers simultaneously should find it beneficial 
to collaborate. The rule for knowledge integration is as follows: the amount of joint knowledge that enters the production function is maximum of what each agent knows in type $j$ and is given by; ${ }^{2}$

$$
k_{j}^{\text {pair }}=\max \left(k_{j}^{i}, k_{j}^{l}\right) \quad \forall j=1 \ldots K
$$

Since there are two knowledge types $(K=2)$, for effective knowledge integration to occur it should be the case that $k_{11}>k_{21}$ and $k_{22}>k_{12}$ (which states that no agent has absolute superiority in both knowledge types). When producers integrate their knowledge, the amount of knowledge that enters the joint production function is given by

$$
\text { Knowledge1 }: \max \left(k_{11}, k_{21}\right)=k_{11}
$$

Knowledge 2: $\max \left(k_{12}, k_{22}\right)=k_{22}$

Let us first take the case of producer 1 . He/she has to decide between producing good 1 alone (Eq. 1), or to produce both goods with producer 2 and get half of total production so that his/her gain in joint production is given by; ${ }^{3}$

$$
y_{n, m}^{\text {pair }}=\frac{y_{n}\left(\mathbf{k}^{\text {pair }}\right)+y_{m}\left(\mathbf{k}^{\text {pair }}\right)}{2}
$$

for $n, m=1,2$ (goods). The question that we address is, for which parameter values and initial knowledge levels will the agents simultaneously prefer to produce together rather than alone?

Proposition 1 In the initial period, two producers will form pairs if and only if the following conditions are satisfied simultaneously;

For producer 1

$$
k_{11}<\left(\frac{2 k_{12}^{\left(1-\gamma_{11}\right)}-k_{22}^{\left(1-\gamma_{11}\right)}}{k_{22}^{\gamma_{22}}}\right)^{\frac{1}{1-\gamma_{11}-\gamma_{22}}}
$$

For producer 2

$$
k_{22}<\left(\frac{\left.2 k_{21}^{\left(1-\gamma_{22}\right)}-k_{11}^{\left(1-\gamma_{11}\right)}\right)}{k_{11}^{\gamma_{11}}}\right)^{\frac{1}{1-\gamma_{11}-\gamma_{22}}}
$$

for $\gamma_{11}+\gamma_{22}>1$.

Proof. See Appendix

Inequalities 4 and 5 imply that the more is the knowledge of the other producer, the more likely will the producer himself be willing to collaborate. Below, we elaborate further on Proposition 1 , in relation to Figure 1. ${ }^{4}$

To make things mathematically tractable, let us assume that $k_{12}=k_{21}=1$. Let us also assume symmetrical weights for the two products. That is to say that, $\gamma_{11}=\gamma_{22}$ and which also implies 
$\gamma_{12}=\gamma_{21}$. As noted above, $\gamma_{11}$ measures the extent of knowledge intensiveness of the products in their respective expert types.

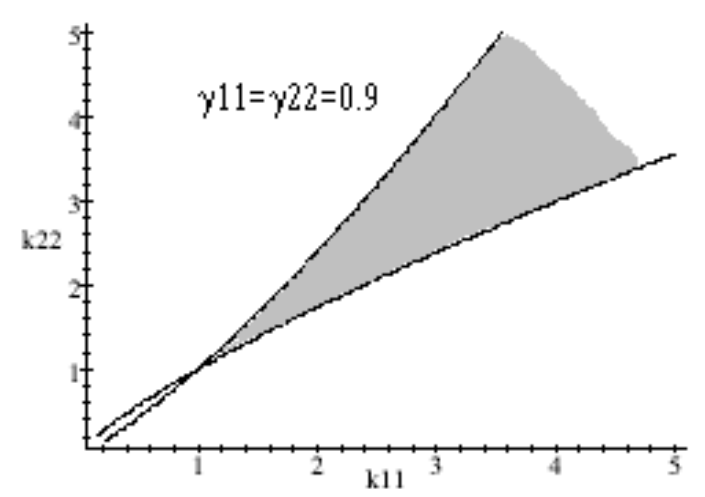

(a)

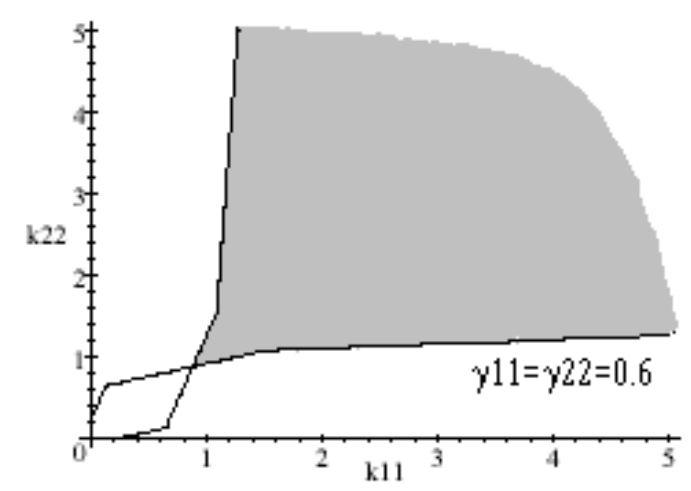

(b)

Figure 1: Collaboration conditions for same major knowledge levels

The shaded areas in Figures 1 (a) and 1 (b) show the areas in which collaboration will take place as a function of the major knowledge levels. Figure 1 is based on inequalities 4 and 5 . The intersection point of the curves is the level of minor knowledge type, which is equal to 1 in (a) and (b). Whether collaboration takes place or not depends on the major and minor knowledge levels of producers and the production parameters. Collaboration can only take place when the major knowledge levels are higher than the minor knowledge levels (that is, major knowledge levels should be greater than 1 in Figure 1). If the initial major knowledge levels are the same (which corresponds to a $45^{\circ}$ line in Figure 1), collaboration will take place on the part of the $45^{\circ}$ line greater than 1 .

Collaboration does not take place in two cases. First when major knowledge types are smaller than minor levels, and second, when the difference between the major knowledge levels among the two producers is very high. This means that expertise level of one producer is too little compared 
to the other producer. So only within a certain limits of major knowledge levels will collaboration take place, and these limits narrow down as $\gamma_{11}$ increases (In Figure 1 (a) the $\gamma_{11}=\gamma_{22}=0.9$ and the area of collaboration is smaller than Figure 1 (b) where $\gamma_{11}=\gamma_{22}=0.6$ ).

Intuitively, this is because higher $\gamma_{11}$ implies lower $\gamma_{12}$, which means that the intensity of the minor knowledge type gets lower. But this means that, the contribution of the partner is lower, which is in the minor category. Therefore the partner should be high enough an expert to compensate for the lower weight of the minor category. Consequently, as $\gamma_{11}$ increases, the area of collaboration falls as shown in Figure 1 (a) in comparison to Figure 1 (b).

To summarize, the likelihood of single production increases as a) $\gamma_{11}, \gamma_{22}$ increases and b) when either partners knowledge level is too low compared to the partner him/herself, since then the higher knowing producer will not be willing to participate. The higher are these production parameters, the less difference among competencies is permitted for collaboration to take place (see Figure 1 (a)).

Corollary 2 The more specialized are the products, the closer the producers should be in their respective expertise fields for collaboration to take place initially. Similarly, the less specialized are the products, collaboration can take place even if the expertise levels are relatively different, i.e. there is a higher difference between their knowledge levels in their respective major categories.

However, the above analysis is only confined to the first period. As productive activities continue learning takes place, and knowledge levels are updated. In the sections below, we incorporate learning effects.

\subsection{Learning}

In the previous section, we analysed the conditions under which collaboration occurs in the initial period. In this section, we analyse the behaviour of the system in the second period, as agents gain experience in the production process and accumulate knowledge. We assume that learning takes place in both types of knowledge. It is learning by doing, and the amount learned depends upon the amount produced. Therefore, the extent that producer $i$ learns depend on the level of producer $j^{\prime} s$ knowledge as well in the case of joint production. In each period, we assume agents re-consider their decision about collaborating, based on the new knowledge levels. The learning function by which knowledge levels are updated is as follows, given for producer $i$ in knowledge type $s$. We also include an uncertainty term in this learning process, as the details are given in the Equation 6.

$$
k_{i s}(t)=k_{i s}(t-1)+\theta_{i} y(t) g(t)
$$




$$
\begin{aligned}
g(t)= & \delta_{i}(t) \text { if } k_{i s}(t-1)>k_{j s}(t-1) \\
& \delta_{i}(t) \frac{k_{i s}(t-1)}{k_{j s}(t-1)} \text { else }
\end{aligned}
$$

where $\theta_{i}$ measures the combinative capability of the agent, and $\delta_{i}(t)$ is an uncertainty effect. Eq. (6) implies that learning is measured by how much the agent can make use of production $y(t)$ (given by 3). This is firstly a function of capability of the agent and relative knowledge levels between the partners.

Firstly, if agent $i$ knows less than his/her partner, the amount of his learning is limited by their relative knowledge levels and his/her capabilities. For example, if his learning capability is too high relative to partner, he can even leapfrog the partner. Secondly, if agent $i$ knows more than his/her partner (agent $j$ ) before production, there is only an uncertainty in his ability to make use of production and increase his knowledge. This is because now there is no other partner from whom he can learn from, since he is already the expert. This is given in the first part of the function $g(t)$. In this case, this can be considered as R\&D. Here, uncertainty is given by the parameter $\delta_{i}(t)$ which is different for all agents in each period. The knowledge types are updated in all the knowledge types that enter the production function of goods produced by the pair or the agent him/herself.

At this point, one question of interest is, will there be collaboration in the second period once there is a collaboration in the first period? In other words, what maintains the continuity of collaborations? For clarification, we denote period 0 by $t-1$ and period 1 by $t$.

The possibilities for collaboration in the second period is given by the following conditions. For analytical tractability we assume that the learning capabilities of producers are the same and $\delta_{i}(t)=1$

Proposition 3 If capability levels are the same among producers, and if there was collaboration in the first period, collaboration will continue in the second period if and only if the following conditions are met for producers 1 and 2 ,

For Producer 1

$$
k_{11}^{1-\gamma_{11}-\gamma_{12}}(t-1)>\left(\frac{2 k_{12}^{1-\gamma_{11}}(t-1)}{k_{22}^{\gamma_{22}}(t-1)}-k_{22}(t-1)^{1-\gamma_{11}-\gamma_{22}}\right) \psi
$$

where

For Producer 2

$$
\psi=\frac{\left(1+\theta \alpha\left[\left(\frac{k_{11}}{k_{22}}\right)^{\gamma_{11}}+\left(\frac{k_{22}}{k_{11}}\right)^{1-\gamma_{22}}\right]\right)^{1-\gamma_{11}-\gamma_{22}}}{\left(1+\theta \alpha\left[\left(\frac{k_{11}}{k_{22}}\right)^{\gamma_{11}-1}+\left(\frac{k_{11}}{k_{22}}\right)^{-\gamma_{22}}\right]\right)^{1-\gamma_{11}-\gamma_{22}}}
$$

$$
k_{22}^{1-\gamma_{11}-\gamma_{12}}(t-1)>\left(\frac{2 k_{21}^{1-\gamma_{22}}(t-1)}{k_{11}^{\gamma_{11}}(t-1)}-k_{11}(t-1)^{1-\gamma_{11}-\gamma_{22}}\right) \phi
$$




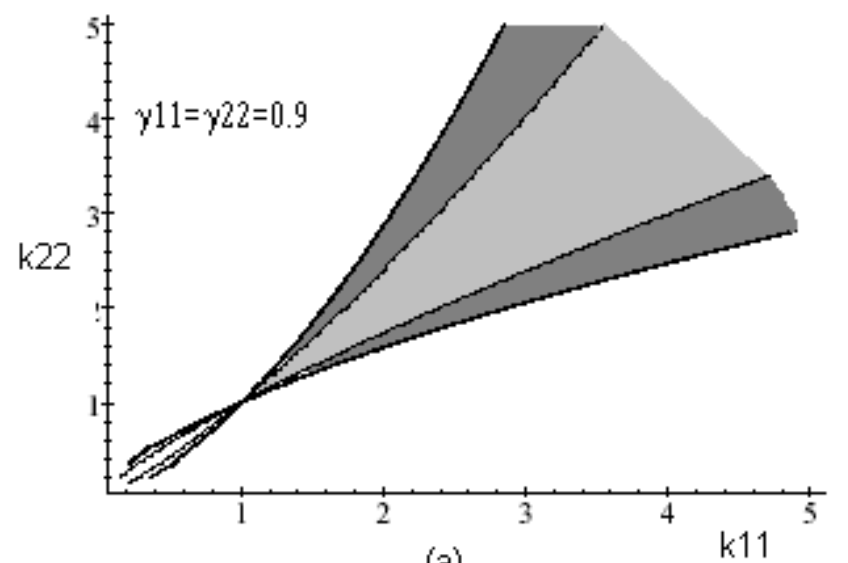

(a)

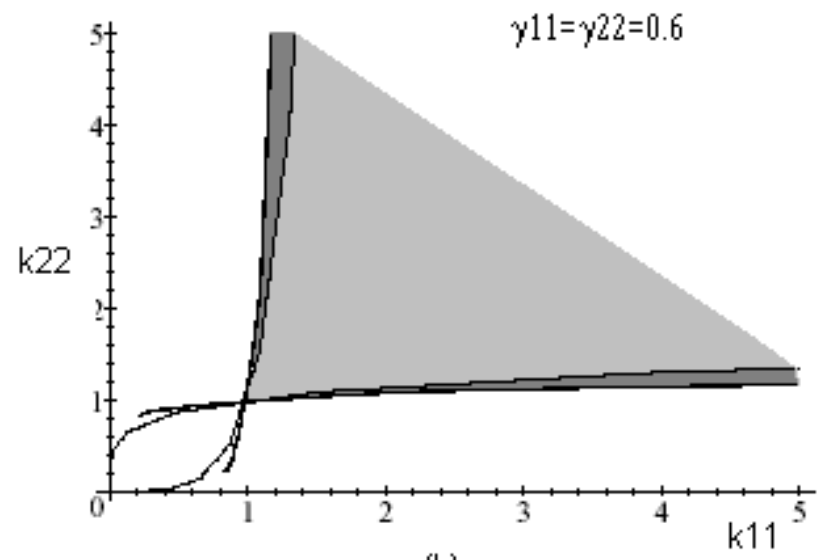

(b)

Figure 2: Second Period Collaboration Conditions

and

Proof. See Appendix

$$
\phi=\frac{1+\theta \alpha\left[\left(\frac{k_{22}}{k_{11}}\right)^{\gamma_{22}}+\left(\frac{k_{22}}{k_{11}}\right)^{1-\gamma_{11}}\right]^{1-\gamma_{11}-\gamma_{22}}}{1+\theta \alpha\left[\left(\frac{k_{22}}{k_{11}}\right)^{\gamma_{22}-1}+\left(\frac{k_{22}}{k_{11}}\right)^{-\gamma_{11}}\right]^{1-\gamma_{11}-\gamma_{22}}}
$$

Proposition 3 is interpreted as follows. Since we assume there is collaboration in the first period, the conditions given by 4 and 5 are already satisfied. The new condition imposed by Proposition is shown by Figure 2 below which is the same as Figure 1 plus the new constraints shown by dark grey areas.

Figure 2 is based on the Equations 7 and 8, where the horizontal and vertical axis are the first period major knowledge levels. Since there was collaboration in the first period by assumption, we are in any point inside the light grey area (this area is the same as Figure 1). The second period constraints are revealed by the addition of the dark grey area. Therefore, for collaboration to continue in the second period, the first period major knowledge levels should be somewhere in 
the total shaded area. If in the first period there was collaboration, this means that collaboration will continue in any case in the second period too, since the light grey area is covered by the total shaded area (light grey and dark grey).

In this section, we presented some analytical results of the model, taking an economy with two producers, two knowledge types and two products. The results highlight the critical role of complementarities in production. Producers will find it profitable to form a collaboration only when they will get higher production by integrating their knowledge is the basic premise of our model. We investigated the role of parameters in influencing the producers willingness to collaborate in subsequent periods.

Although this model gives a basic idea on the logic of knowledge integration and production, the real world case is far more complicated than what this simple model reveals. When there are more than 2 producers in the economy, the dynamics are inevitably more complicated, since the choice set of the agent is proportional to the number of other producers, whether to produce singly or considering all the other producers to collaborate. Moreover, once a collaboration occurs between two agents at a certain period, in the next period, the agents might collaborate with others, and collaborate with each other again in the following period. Also in this section we took into account the deterministic case. In real world the extent of learning is highly uncertain. When such situations are taken into account, the dynamics of knowledge and dynamics of interaction is too complex to handle with analytical tools. Therefore, we perform an agent based simulation study,

\section{Simulations}

\subsection{General}

In this section we extend the analysis to incorporate a larger number of producers, goods and knowledge types, and we carry out a simulation analysis on the resulting interaction patterns among agents.

There are 5 goods, 5 knowledge types, and 50 agents in the economy. Each agent $i$ is endowed with a knowledge vector, $\mathbf{k}^{i}$ assigned randomly (drawn from a uniform distribution) at period $t=0$; $k_{i j}$ shows the level of agent $i$ 's knowledge in type $j$. There exist a knowledge type $j$ for all $i$ such that $k_{i j}>k_{i m} \forall m \neq j .{ }^{5}$ Given his/her knowledge vector, each agent in each period produces a good. But an agent can produce singly, or integrate his/her knowledge with another agent and produce together. If an agent $i$ produces singly, the probability that he/she will produce good $n$ is proportional to the weight of his expertise type $j$ required by the good. ${ }^{6}$ We adopt the term $n$-type agent if the agent produces good $n$. The amount that he/she produces singly is given by 
$y_{n}^{i}$ as given by Eq. 1 .

Each agent, in each period $t$, selects between producing as single or producing in a pair with another agent. In making this decision, the agent's criteria is to maximise his/her output. Therefore, he makes a comparison between his/her joint output with all other agents in the economy and what he/she will produce alone. Joint production happens through integration of knowledge of the two agents. When an $n$-type agent and a $m$-type agent form a pair, we assume they produce both goods $n$ and $m$. It is assumed that if two agents $i$ and $l$ collaborate $(n-t y p e$ and $m$-type respectively), their joint knowledge in category $j$ is given by Eq. 2 which enters the production function of both goods according to Eq. 1 and shared among them according to Eq. 3. Therefore, agent $i$ compares his/her single output $y_{n}^{i}$ with $y_{n, m}^{\text {pair }}$ with all other agents. Here, it is assumed that agents know the knowledge levels of the other agents. Every agent has a preference listing (other agents ranked according to the maximum output they can produce with him/her). In practice, pairing in the population is made in such a way that no two agents prefer each other to their current partners. As different from the marriage problem, where there are two different populations, this is termed to be the room-mate problem, where pairs are formed within a single population [19]. Within a similar framework as this paper, Cowan et. al [20] utilize this matching algorithm for analysing the network dynamics resulting from joint innovation by interaction and knowledge integration of agents. After production, learning takes place according to Eq. 6, pairs dissolve and next period expertise areas are updated, and new pairs form.

One of the values that we are interested is the relatedness among two goods. The production parameters can be used to derive a measure of relatedness. We assume that, the more similar is the knowledge requirements of two goods, the more related they are. We measure relatedness among two goods by the cosine of the angle between them. More specifically, the cosine index between two products $n$ and $m$ is given by;

$$
\cos _{m n}=\frac{\sum_{i=1}^{K} \gamma_{n i} \gamma_{m i}}{\sqrt{\sum_{i=1}^{K} \gamma_{n i}^{2}} \sqrt{\sum_{i=1}^{K} \gamma_{m i}^{2}}}
$$

Obviously, $\cos _{n n}=1$, and if there is no common knowledge between the goods, $\cos _{m n}=0$. Other cases fall in between the two extremes. Therefore, high cosine values indicate increased relatedness between two products, in terms of similarity in their knowledge requirements. The relatedness between the goods is represented by the symmetric matrix $C O S(M \times M)$, where $\cos _{i j}$ gives the cosine between products $i$ and $j$.

The model consists of a setting in which all goods have an equal number of knowledge inputs but with different intensities in each separate simulation. We aim to highlight how the resulting 


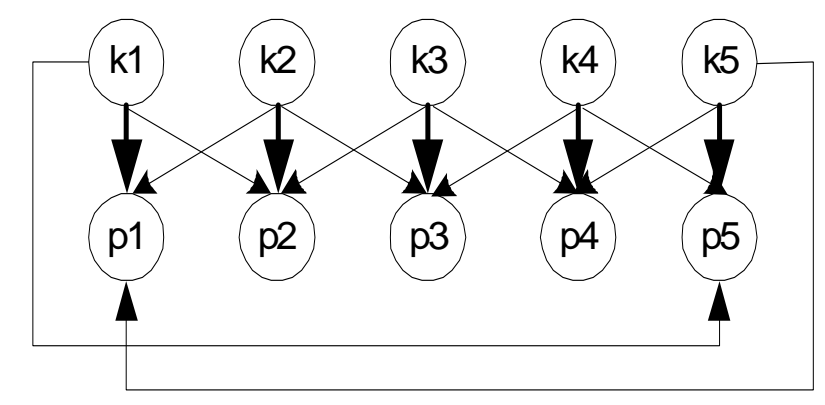

Figure 3: A Schematic Representation of Knowledge and Products

Table 1: Representation of the Matrix of Input Coefficients

\begin{tabular}{c|ccccc} 
& $\mathrm{k}_{1}$ & $\mathrm{k}_{2}$ & $\mathrm{k}_{3}$ & $\mathrm{k}_{4}$ & $\mathrm{k}_{5}$ \\
\hline $\mathrm{p}_{1}$ & $\gamma_{1}$ & $\gamma_{3}$ & 0 & 0 & $\gamma_{2}$ \\
$\mathrm{p}_{2}$ & $\gamma_{2}$ & $\gamma_{1}$ & $\gamma_{3}$ & 0 & 0 \\
$\mathrm{p}_{3}$ & 0 & $\gamma_{2}$ & $\gamma_{1}$ & $\gamma_{3}$ & 0 \\
$\mathrm{p}_{4}$ & 0 & 0 & $\gamma_{2}$ & $\gamma_{1}$ & $\gamma_{3}$ \\
$\mathrm{p}_{5}$ & $\gamma_{3}$ & 0 & 0 & $\gamma_{2}$ & $\gamma_{1}$
\end{tabular}

interaction patterns are influenced when goods use one knowledge intensively, or when they have a more distributed knowledge base with equal shares of all goods.

\subsection{Modelling the Knowledge Base}

It is possible to demonstrate the knowledge base of goods by a simple network, as Figure 3 demonstrates.

Figure 3 shows that each of the goods (shown by $p$ ) require three consecutive knowledge types, one of which, shown by the bold arrow is used more intensively. In this way, two consecutive goods have two knowledge types in common, but what is a major input in one is only minor in the other. The relative weights of these knowledge types is the production parameters of the good. As a demonstration, the production parameters corresponding to this scheme is given by Table 1 where the rows and columns represent goods and knowledge types respectively, and $\gamma_{i j}$ gives the weight of knowledge $j$ in good $i .^{7}$

Since we assume constant returns to scale, the row sums are one (i.e. $\gamma_{1}+\gamma_{2}+\gamma_{3}=1$ ). Also there is one knowledge type that is more intensively used than the others, $\gamma_{1}>\gamma_{2}$ and $\gamma_{1}>\gamma_{3}$. The gamma values in different simulations range between two extreme cases: on one hand, we take the case where the goods are totally distinct from each other, where they share no knowledge in common. This corresponds to the case where, 
Table 2: The Case of No Relatedness in Goods, Cosine Matrix

\begin{tabular}{c|ccccc} 
& $\mathrm{p}_{1}$ & $\mathrm{p}_{2}$ & $\mathrm{p}_{3}$ & $\mathrm{p}_{4}$ & $\mathrm{p}_{5}$ \\
\hline $\mathrm{p}_{1}$ & 1 & 0 & 0 & 0 & 0 \\
$\mathrm{p}_{2}$ & 0 & 1 & 0 & 0 & 0 \\
$\mathrm{p}_{3}$ & 0 & 0 & 1 & 0 & 0 \\
$\mathrm{p}_{4}$ & 0 & 0 & 0 & 1 & 0 \\
$\mathrm{p}_{5}$ & 0 & 0 & 0 & 0 & 1
\end{tabular}

Table 3: Maximum Relatedness among Goods, Cosine Matrix

\begin{tabular}{c|ccccc} 
& $\mathrm{p}_{1}$ & $\mathrm{p}_{2}$ & $\mathrm{p}_{3}$ & $\mathrm{p}_{4}$ & $\mathrm{p}_{5}$ \\
\hline $\mathrm{p}_{1}$ & 1 & $2 / 3$ & $1 / 3$ & $1 / 3$ & $2 / 3$ \\
$\mathrm{p}_{2}$ & $2 / 3$ & 1 & $2 / 3$ & $1 / 3$ & $1 / 3$ \\
$\mathrm{p}_{3}$ & $1 / 3$ & $2 / 3$ & 1 & $2 / 3$ & $1 / 3$ \\
$\mathrm{p}_{4}$ & $1 / 3$ & $1 / 3$ & $2 / 3$ & 1 & $2 / 3$ \\
$\mathrm{p}_{5}$ & $2 / 3$ & $1 / 3$ & $1 / 3$ & $2 / 3$ & 1
\end{tabular}

$$
\begin{aligned}
& \gamma_{1}=1 \\
& \gamma_{2}=\gamma_{3}=0
\end{aligned}
$$

Corresponding to this case, the COS matrix is given by Table 2 .

In the other extreme, we take the case where relatedness is maximum among the products. Therefore,

$$
\gamma_{1}=\gamma_{2}=\gamma_{3}=1 / 3
$$

The corresponding COS matrix is given by Table 3 .

This specification implies that, relatedness between two consecutive goods, $i$ and $i+1$ is higher than the relatedness between $i$ and $i+2 .^{8}$ The main parameter that is varied in different simulations is the production parameters that are inputs in the production function (given by Eq. 1 and Table 1). From the production parameters, we derive measures of relatedness using Eq. 9 computed by the average of the elements of the COS matrix. In this specification, it is easy to see that as the weight of the major knowledge type falls, the relatedness between two consecutive goods increase and this is when the goods utilize a more distributed set of knowledge inputs. On the other hand increased dominance of the major knowledge type implies that goods are less related, and we call these goods specialized goods. 
We carry out 40 simulation runs. In each of these runs, a different set of input coefficients are used for the 5 goods. On one extreme, we have the case given by Eq. 10 and on the other extreme we have the case given by Eq. 11. In between cases consist of parameters which yield intermediate levels of relatedness among the products. We present the results with respect to the relatedness measures, which are derived by taking the average of the cosine matrices that correspond to each set of input coefficients in different runs. ${ }^{9}$

In each of the runs there are 10,000 periods. In each period, matching takes place, pairs form and produce according to Eq. 1 and agents update their knowledge according to Eq. 6. In each period who forms a pair with who is recorded as an adjacency matrix. We take into account only bilateral link formation in a single period, but when sufficient time periods elapse, these bilateral links form a network, and a certain network structure emerges. We consider the results when the network stops changing, i.e. when the stability in the network is achieved. The results are based on the frequency matrices of the last $500 \pm 10$ periods. The uncertainty parameter $\delta_{k}(t) \in[0.95,1.05]$ and capabilities are $\theta_{k} \in[0.8,1.2] .^{10}$

\section{Results}

\subsection{Network Density}

Firstly we looked at the density of the final networks. ${ }^{11}$ It is given by:

$$
D=\frac{\sum_{i=1}^{N} \sum_{j=1}^{N} x_{i j}}{N(N-1)}
$$

where $x_{i j}=1$ if there is an edge between $i$ and $j$ and 0 otherwise and $N$ is the total number of nodes. ${ }^{12}$ The denominator measures total number of available links in the network, and numerator measures the number of existing links.

Figure 4 depicts two results. Firstly, there is a clear negative relationship between relatedness and network density. As the relatedness among the products increase, the density of the network falls (lowest density occurring for the case of Eq. (11) above). Here, the density of the network measures the variety in the network. In other words, if the same agents form pairs all the time, or if production occurs mostly singly, network density is low. High network density occurs when different agents form pairs, which increases the number of links in the network. In this case, we see that highest variety occurs when there is little relatedness among the products (which means that agents change their partners frequently).

The second result that can be deduced from Figure 4 is the discontinuity observed when the products are totally unrelated, that is the leftmost point (corresponding to the case Eq. (10) above). 


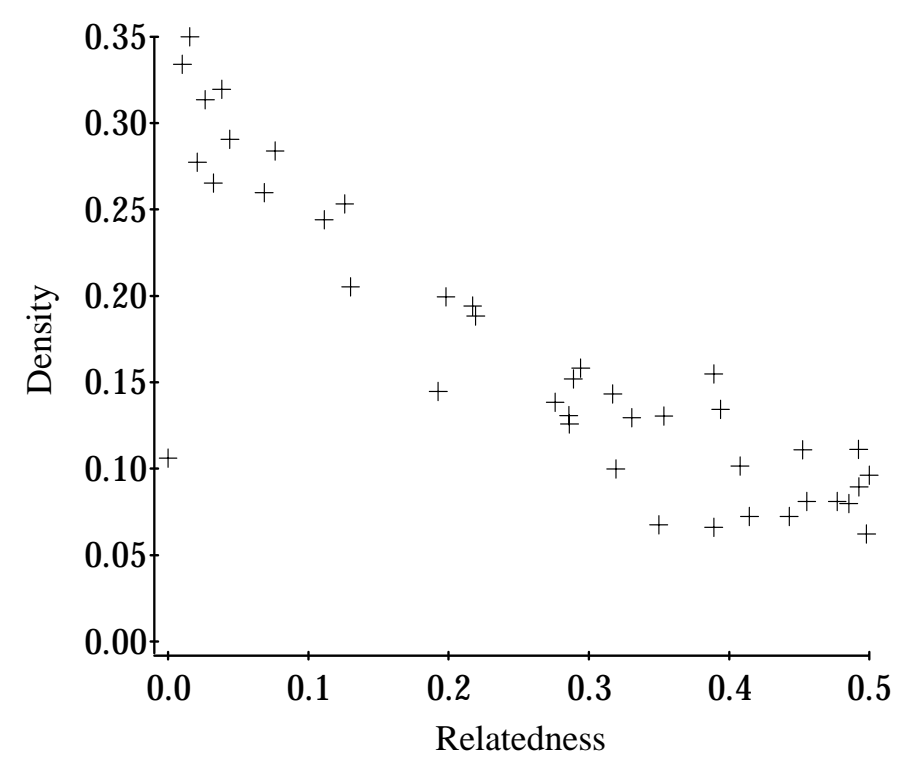

Figure 4: Network Density

Here, it is possible to see that the network density is very low, which means that when the goods are unrelated to each other, either there is single production (which will reduce network density), or the same agents tend to form pairs all the time so that there is no variety in the network. ${ }^{13}$ In other words, all agents will produce the goods that require most of their own expertise and if they integrate their knowledge, they do so with agents of the same type. ${ }^{14}$ This discontinuity is also observed in the remaining parts of the results below.

\subsection{Geodesics}

Figure 5 shows the shortest path between reachable and all nodes in the network. It confirms the reduced interaction among agents as goods become more related. It is also interesting to note that, as relatedness rises, not only the geodesic between all pairs increase, but also the average geodesic between only reachable pairs rise. As it is shown further below, this implies that clustering increases (the case of totally isolated pairs being the extreme case) as goods become more related.

\subsection{Clustering Coefficient}

Figure 6 shows that the clustering in the network increases significantly as relatedness increases. This is largely because when there is a high degree of relatedness among the goods, the same agents interact, or agents produce singly. This reduces both the density of the network, and also increases the extent of isolated pairs who collaborate consistently or single producers. 


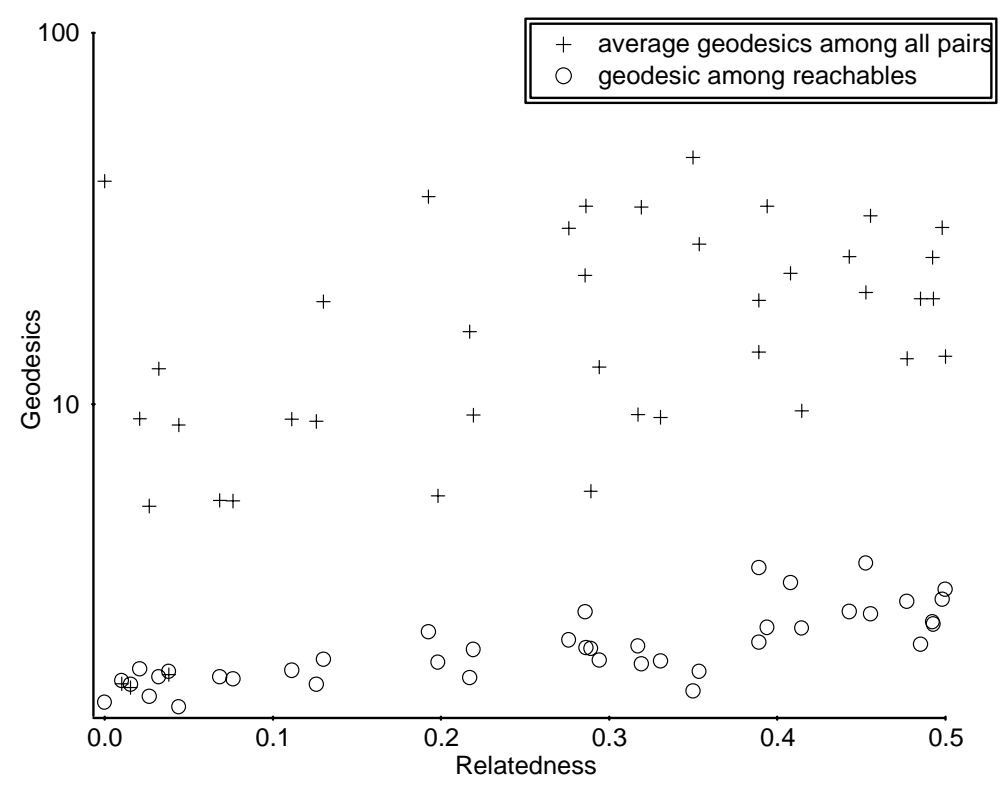

Figure 5: Geodesics and Relatedness

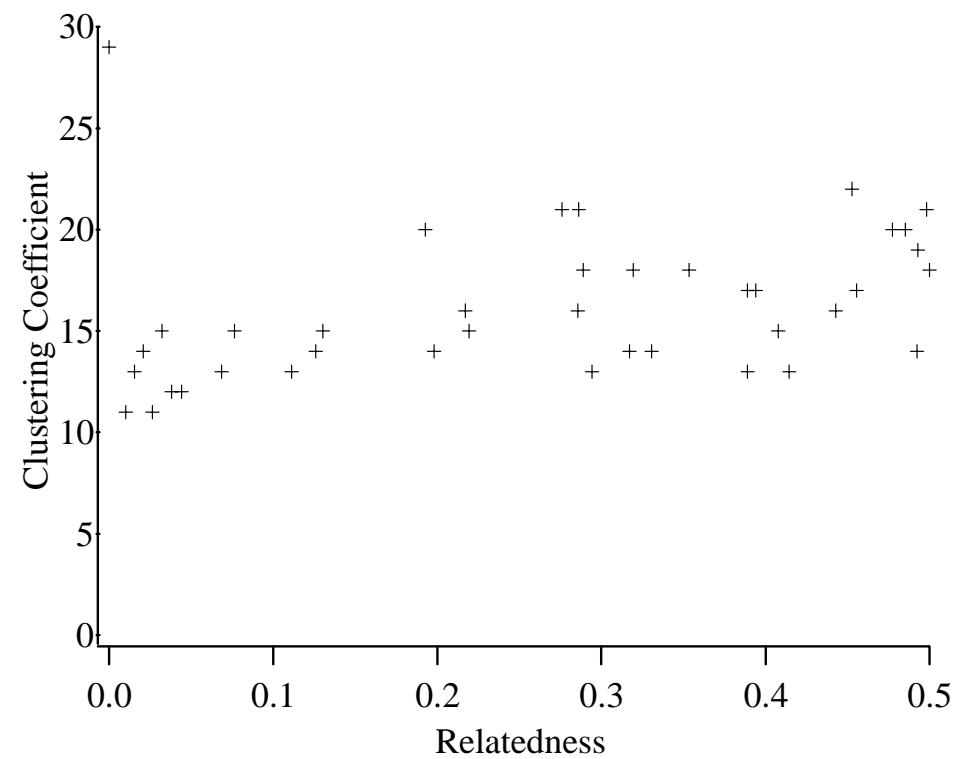

Figure 6: Clustering Coefficients and Relatedness 


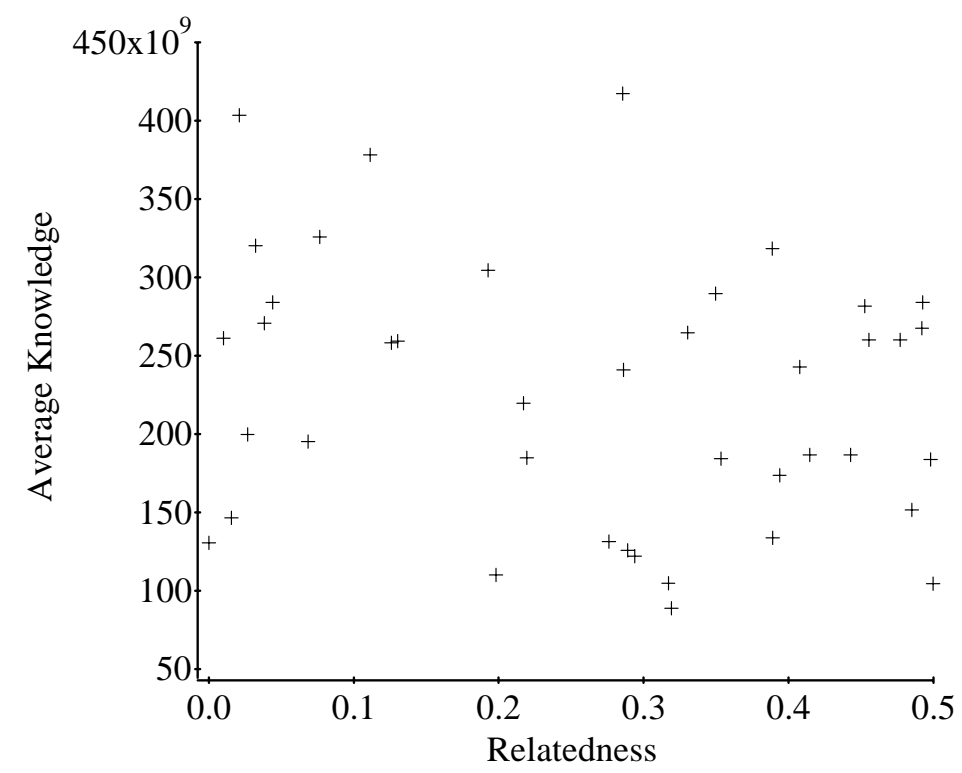

Figure 7: Average Knowledge and Relatedness

\subsection{Knowledge Dynamics}

In Figure 7 we present the average knowledge levels with respect to relatedness. Despite high variance, it is possible to see a slight fall in average knowledge level as relatedness increases. This also implies that high networking (high density) also implies high average knowledge levels.

We also analysed the expertise levels, as Figure 8 shows, which we measured by the Blau index [22] in the final periods for each run. The weight of knowledge $g$ in the total amount of knowledge for agent $i$ in all types of knowledge is given by;

$$
w_{g}^{i}=\frac{k_{g}^{i}}{\sum_{j=1}^{K} k_{j}^{i}}
$$

The extent to which an agent is a specialist (the extent to which the agent knows a certain knowledge type more than the others) is measured by;

$$
\operatorname{Exp}_{i}=\frac{1}{1-\left(\sum_{j=1}^{K}\left(w_{j}^{i}\right)^{2}\right)}
$$

As Figure 8 reveals (showing the average of $\operatorname{Exp}_{i}$ taken over all agents for each run), expertise level is highest when the products are completely unrelated (case Eq. (10) above). ${ }^{15}$ However, it is interesting to observe that when goods are even slightly related to each other, expertise levels are significantly lower, and increases thereof. Intuitively, this can be explained by the density pattern as shown in Figure 4. When the relatedness is low, density is high (which reveals that there is 


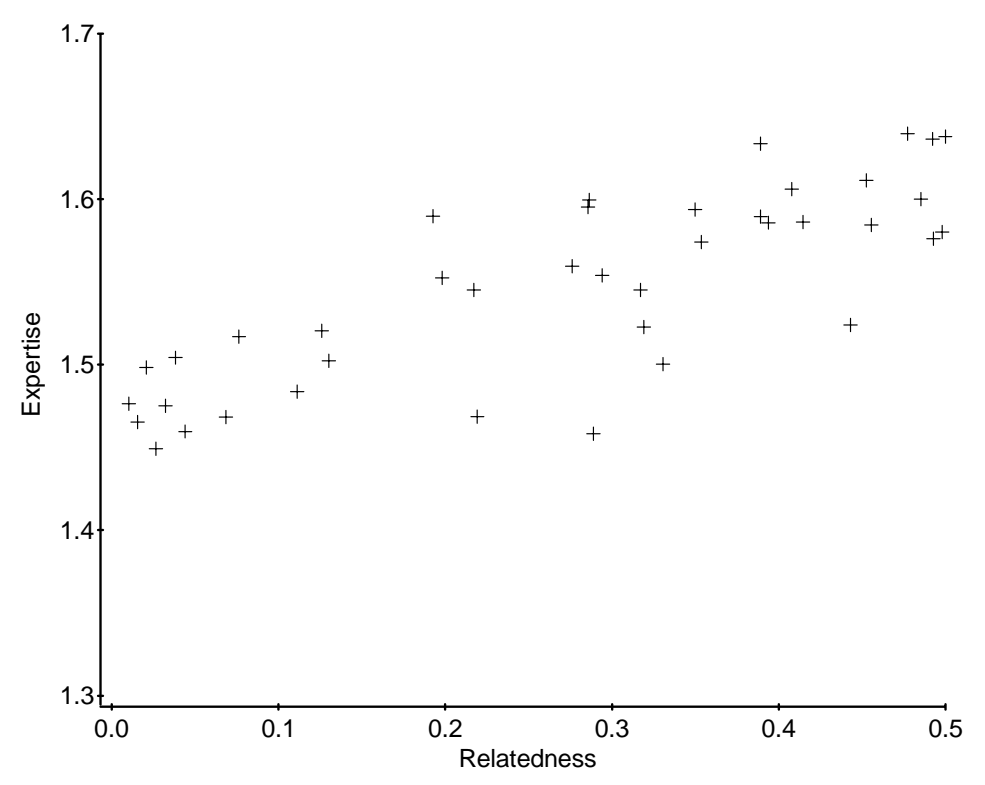

Figure 8: Expertise and Relatedness

high variety in the interaction patterns, i.e. different agents form pairs). When this is the case, agents learn in a wider range of knowledge types, and one of the reasons of variety in pairs is that expertise types also change more frequently in the population (agents shift their expertise). The average change of expertise is demonstrated in Figure 9. Whereas when relatedness is high, same agents join for production so that the density is low. This implies that they learn in a limited number of knowledge types. This increases expertise levels in the population.

\section{Discussion and Conclusion}

According to our results, the knowledge regime in the industry has a significant effect on the structure and intensity of interactions. One of the results that both our simulations and analytical model reveal is that collaboration takes place when there are gains from knowledge integration, which depends on the structure of goods. In a two-producer, two-good economy, the more specialized are the products (and thus the less related they are), the more important it becomes to have similar expertise levels for each party to benefit from collaboration, so that there are less possibilities for collaboration when agents are too far apart in terms of their endowments. Contrarily, when there are many producers, specialization of the goods results in intensive interactions among various pairs since there are many partners to select from so that different agents form pairs mostly (which increases the density of the network). Therefore the restrictions of the two producer economy is not valid. Also in this case, variety in the pairs result in agents who learn in a diverse range of fields, 


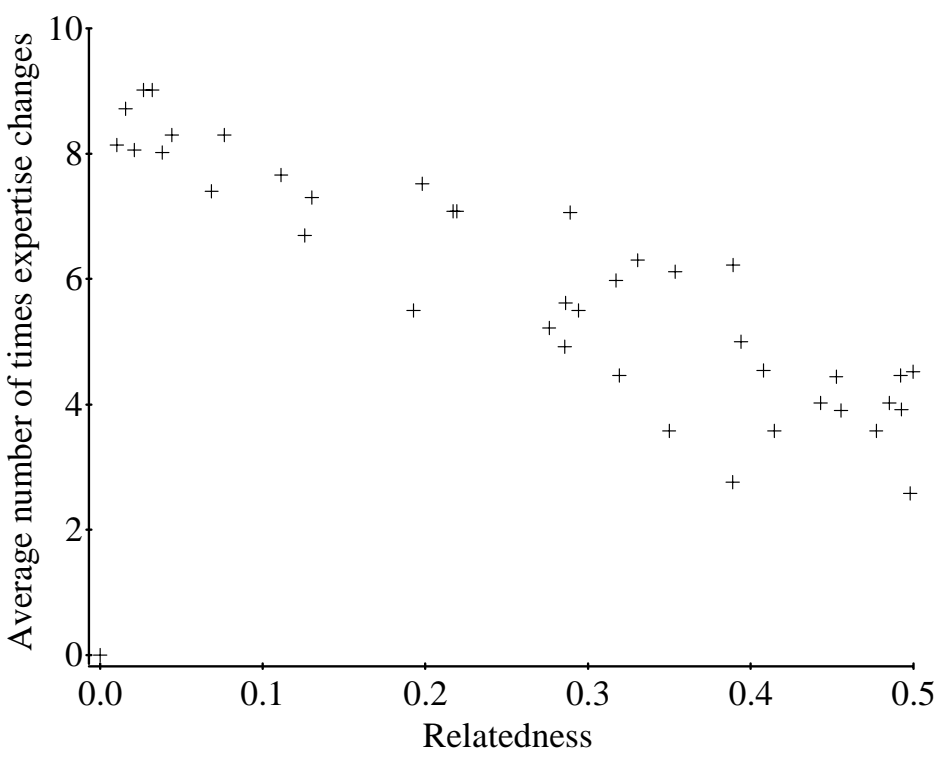

Figure 9: Frequency of Change in Expertise and Relatedness

which reduces expertise and results in a population in which knowledge is more distributed. When this is the case, the fields that agents know most about also change frequently, which increases the density of the network. Although weakly, we can also infer that knowledge levels tend to fall as relatedness increases which might be because of lower density in the network. This lower density also implies that clustering in the network increases, which is to say that the same agents form pairs consistently, or single production prevails.

These results point to the importance of complementarities among products, and their implications for collaboration patterns. According to Mowery et. al. [11] there is an inverted-u relation between cognitive distance among actors and gains from integration. They carry out an empirical study to show that if the knowledge overlap is too high among firms, there is nothing to be gained. If too distant, there is limited cognitive ability to understand. In this paper, we consider the structure of the goods explicitly, and explain how the distance between two goods in knowledge space is mapped onto the interactions among agents who embody the knowledge the produce these goods. We find that when the goods are too similar, there is hardly any benefits from collaboration. When they are not related at all, there is also no benefit form collaborating. Only when there is a low degree of relatedness, so that a major input in one good is only minor in the others, do we see high benefits from integration of knowledge and high network density.

These results have direct bearing on the innovation policies. Innovation policies directed towards deepening of the knowledge base (so that the products become more specialized in their composition of certain inputs) increases the intensity of interactions, the average knowledge levels, and also it 
results in a more distributed knowledge among producers.

Obviously, there are many factors other than the knowledge base that influence networks as a growing literature reveals, ranging from institutional factors, stage in the industry life cycle, demand side effects, cost considerations, firm strategies and many more. Nevertheless, in a world in which knowledge is in the core of both business and academia, and in which networks are the main mechanism through which knowledge diffuses, the impact of knowledge bases on network structure deserves a central role. 


\section{Notes}

${ }^{1}$ Specifically, the choice faced by producer 1 can be expressed as, $\max \left(y_{1}^{1}, y_{2}^{1}\right)=\max \left(k_{11}^{\gamma_{11}} k_{12}^{\left(1-\gamma_{11}\right)}, k_{11}^{\left(1-\gamma_{22}\right)} k_{12}^{\gamma_{22}}\right)$. Producer 1 will produce good 1 if the following condition holds; $k_{11}^{\gamma_{11}} k_{12}^{\left(1-\gamma_{11}\right)}>k_{11}^{\left(1-\gamma_{22}\right)} k_{12}^{\gamma_{22}}$ which is equivalent to $k_{11}^{\gamma_{11}+\gamma_{22}-1}>k_{12}^{\gamma_{11}+\gamma_{22}-1}$ and since $k_{11}>k_{12}$ from our assumption above, producer 1 produces good 1 . Analogously, when alone, producer 2 produces good 2 .

${ }^{2}$ Here we assume that once producers decide to collaborate, then they contribute with all their endowment, in other words they reveal all their knowledge in the production.

${ }^{3}$ We make the $50 \%$ split rule based on the following intuition. If the knowledge levels among the two producers are too different (if one of them is much more knowledgeable than the other), than collaboration will not take place in any case, as we demonstrate below. Therefore, the two producers should be sufficiently close to each other in their relative expertise areas if they are to collaborate. Therefore, it is reasonable to assume that they share production output equally. This rule also takes into account the fact that the relative price levels are unity.

${ }^{4}$ It follows directly from Proposition 1 that, when initial major knowledge levels are the same for both producers $\left(k_{11}=k_{22}\right)$, collaboration will take place in the first period if and only if $k_{22}>k_{21}$ and $k_{22}>k_{21}$. Therefore, if the initial knowledge levels in the major knowledge types are the same, then there will always be collaboration, since by our assumption above producer 1 is an expert in area $1\left(k_{11}>k_{12}\right)$ and producer 2 is an expert in area $2\left(k_{22}>k_{21}\right)$.

${ }^{5}$ The knowledge setting used here is first introduced by Cowan et. al [20]. Specifically, $k_{i j}=k_{h j}$ means that agents $i$ and $h$ have exactly the same knowledge in type $j$. If $k_{i j}>k_{h j}$ agent $i$ knows everything that agent $h$ knows in type $j$, and has some knowledge in addition.

${ }^{6}$ If product $n$ uses $90 \%$ of knowledge type $j$, then there is 0.9 probability that agent $i$ produces good $n$.

${ }^{7}$ In Table 1, we do not use double subscripts for purposes of clarity, since the elements of the matrix represent the same numerical values.

${ }^{8}$ To see why this is so, see Table 1. For example, between products 1 and 2 , here are two common knowledge types, namely $k_{1}$ and $k_{2}$ so that the relatedness among them is higher than products 1 and 3 where they have only $k_{2}$ in common.

${ }^{9} \mathrm{As}$ an example, in the case where $\gamma_{2}=0.99$ and $\gamma_{1}=\gamma_{3}=0.005$, even though there is a certain relatedness between two consecutive goods it is sufficiently small, since only 0.5 percent of a particular knowledge type is shared between them.

${ }^{10}$ Different paramater ranges were tried to test for the robustness of the results. The results do not change significantly, except that higher values of uncertainty parameter has the effect of increasing the absolute levels of network density.

${ }^{11}$ In the rest of the paper, software UCINET is used for give network measures (Borgatti et. al., [21]).

${ }^{12}$ The matrices upon which the density measures are based on is derived from the frequency matrices. When there is a link between two agents, the value is set to 1 , otherwise 0 . Therefore, an edge between two agents mean that they have formed a pair at least once in $500 \pm 10$ periods. We use the frequency values in the analysis below.

${ }^{13}$ In this case, producing singly is higher than other cases.

${ }^{14}$ Integrating knowledge with another agent of the same type will require that one agent knows one minor type better and the other agent knows the other minor type better so that there is still motivation for integration of knowledge.

${ }^{15}$ Because the expertise index is extremely large in this case, it is not shown in Figure 8. 


\section{References}

[1] C. Jones, W.S., Hesterly, and S.P., Borgatti, A General Theory of Network Governance: Exchange Conditions and Social Mechanisms, Academy of Management Journal, 22: 911-45, (1997).

[2] J. Hagedoorn, Understanding the Rationale of Strategic Technology Partnering: Interorganizational Modes of Cooperation and Sectoral Differences, Strategic Management Journal, 14: 371-85, (1993).

[3] R., Allen, Collective Invention, Journal of Economic Behavior and Organization, 4: 1-24, (1983).

[4] E. Von Hippel, Cooperation Between Rivals: Informal Know-how Trading, in B. Carlsson (ed.), Industrial Dynamics, Technological Organizational and Structural Changes in Industries and Firms, Kluwer, Boston, pp 157-176, 1989.

[5] B. Uzzi, Social Structure and Competition in Interfirm Networks: The Paradox of Embeddedness, Administrative Science Quarterly, 42(1): 35-67, (1997).

[6] R. Gulati, Network Location and Learning: the Influence of Network Resources and Firm Capabilities on Alliance Formation, Strategic Management Journal, 20: 397-420, (1999).

[7] T. Rowley, D. Behrens, and D. Krackhardt, Redundant Governance Structures: An Analysis of Structural ad Relational Embeddedness in the Steel and, Semiconductor Industries, Strategic Management Journal, 21: 369-86, (2000).

[8] J. Hite and W.S. Hesterly, The Evolution of Firm Networks: From Emergence to Early Growth of the Firm, Strategic Management Journal, 22: 275-286, (2001).

[9] L. Rosenkopf, M.L. Tushman, The Coevolution of Community Networks and Technology: Lessons From the Flight Simulation Industry, Industrial and Corporate Change, 7: 311-46, (1998).

[10] R. Madhavan, B. Koka and E. Prescott, Networks in Transition: How Industry Events (Re)Shape Interfirm Relationships, Strategic Management Journal, 19: 439-59, (1998).

[11] D.C. Mowery, J.E. Oxley and B.S. Silverman, Technological Overlap and Interfirm Cooperation: Implications for the Resource Based View of the Firm, Research Policy, 27: 507-23, (1998). 
[12] T.E. Stuart, and J.M. Podolny, Local Search and the Evolution of Technological Capabilities, Strategic Management Journal, 17, Special Issue: Evolutionary Perspectives on Strategy. pp. 21-38, (1996).

[13] T.E. Stuart, T.E., Network Positions and Propensities to Collaborate: An Investigation of Strategic Alliance Formation in a High Technology Industry, Administrative Science Quarterly, 43: 668-98, 1998.

[14] L. Nesta and V. Mangematin, Industry Life Cycle, Knowledge Generation and Technological Networks, in: J. De la Mothe and A.N. Link (eds) Networks, Alliances and Partnerships in the Innovation Process, Kluwer Academic, Dordrecht, 2002.

[15] K. Frenken, K., A Complexity Approach to Innovation Networks: The Case of the aircraft industry, Research Policy, 29: 257-72, (2000).

[16] J. Birkinshaw, R. Nobel, and J. Ridderstrale, Knowledge as a Contingency Variable: Do the Characteristics of Knowledge Predict Organization Structure?, Organization Science, 13(3): 274-289, (2001).

[17] L. Orsenigo, F. Pammoli, M. Riccaboni, A. Bonaccorsi, and G. Turchetti, G. The Evolution of Knowledge and the Dynamics of an Industry Network, Journal of Management and Governance, 1:147-175, (1998).

[18] R. Cowan, N. Jonard and M. Ozman, Knowledge Dynamics in a Network Industry, Technological Forecasting and Social Change, 71(5): 469-84, (2004).

[19] D. Gale, and L. Shapley, College Admissions and the Stability of marriage, American Mathematical Monthly, 69: 9-15, (1967).

[20] R. Cowan, N. Jonard, and J. Zimmermann, The Joint Dynamics of Networks and Knowledge, Gallegati, D., M. Marsili (Eds.), Springer, Lecture Notes in Economics and Mathematical Systems, 521: 155-174, (2002).

[21] S.P. Borgatti, M.G. Everett, L.C. and Freeman, UCINET for Windows: Software for Social Network Analysis, Harvard: Analytic Technologies, 2002.

[22] P. Blau, Heterogeneity and Inequality, New York: Free Press, 1977. 


\section{Appendix}

\section{Proposition 1}

Proof. To be able to find this we need to look at the indifference function for both producers, which shows the critical production levels at which the producers are indifferent between producing singleton or together. Let us consider producer 1 first. The indifference equation is given by

$$
\alpha \underbrace{k_{11}^{\gamma_{11}} k_{12}^{\gamma_{12}}}_{\text {producer 1, good 1, singleton }}=\frac{1}{2} \alpha \underbrace{\left[k_{11}^{\gamma_{11}} k_{22}^{\gamma_{12}}\right.}_{\text {paired, good 1 }}+\underbrace{k_{11}^{\gamma_{21}} k_{22}^{\gamma_{22}}}_{\text {paired, good } 2}]
$$

In the same way, indifference condition for producer 2 is given by

$$
\underbrace{k_{21}^{\gamma_{21}} k_{22}^{\gamma_{22}}}_{\text {producer 2, good 2, singleton }}=\frac{1}{2} \underbrace{\left[k_{11}^{\gamma_{11}} k_{22}^{\gamma_{12}}\right.}_{\text {paired, good 1 }}+\underbrace{k_{11}^{\gamma_{21}} k_{22}^{\gamma_{22}}}_{\text {paired, good 2 }}]
$$

Rearranging terms for producer 1 we get the following indifference condition

$$
k_{11}^{\gamma_{11}} k_{22}^{\gamma_{12}}-k_{11}^{\gamma_{11}} k_{12}^{\gamma_{12}}=k_{11}^{\gamma_{11}} k_{12}^{\gamma_{12}}-k_{11}^{\gamma_{21}} k_{22}^{\gamma_{22}}
$$

The interpretation of the equation is straightforward, which represents the trade-off faced by producer 1 . The LHS shows the net gain in producing good 1 as a pair. This is equal to producing good 1 as a pair, less the opportunity cost which is producing good 1 singleton. The RHS shows, on other hand, the net loss from producing as a pair. This is equivalent to what producer 1 could have produced singleton, less the additional good 2 he gets by collaborating. If the RHS of equation 12 is greater then the LHS, producer will prefer singleton. Therefore the condition for collaboration is given by

$$
\alpha k_{11}^{\gamma_{11}} k_{12}^{\gamma_{12}}<\frac{\alpha k_{11}^{\gamma_{11}} k_{22}^{\gamma_{12}}+\alpha k_{11}^{\gamma_{21}} k_{22}^{\gamma_{22}}}{2}
$$

Rearranging terms we get the condition for producer 1's willingness to collaborate:

$$
\begin{gathered}
k_{11}^{1-\gamma_{11}-\gamma_{22}}>\frac{2 k_{12}^{\left(1-\gamma_{11}\right)}-k_{22}^{\left(1-\gamma_{11}\right)}}{k_{22}^{\gamma_{22}}} \\
k_{11}<\left(\frac{2 k_{12}^{\left(1-\gamma_{11}\right)}-k_{22}^{\left(1-\gamma_{11}\right)}}{k_{22}^{\gamma_{22}}}\right)^{1 /\left(1-\gamma_{11}-\gamma_{22}\right)}
\end{gathered}
$$

\section{Proposition 2}

Proof. In this case the new knowledge levels are

$$
\begin{aligned}
& k_{11}(t)=k_{11}(t-1)\left[1+\theta \alpha / 2\left(\left(\frac{k_{22}(t-1)}{k_{11}(t-1)}\right)^{\gamma_{12}}+\left(\frac{k_{22}(t-1}{k_{11}(t-1)}\right)^{\gamma_{22}}\right)\right] \\
& k_{22}(t)=k_{22}(t-1)\left[1+\theta \alpha / 2\left(\left(\frac{k_{11}(t-1)}{k_{22}(t-1)}\right)^{\gamma_{11}}+\left(\frac{k_{11}(t-1)}{k_{22}(t-1)}\right)^{\gamma_{21}}\right)\right]
\end{aligned}
$$




$$
k_{12}(t)=k_{12}(t-1)\left[1+\theta \alpha / 2\left(\frac{k_{11}^{\gamma_{11}}(t-1)}{k_{22}^{\gamma_{11}}(t-1)}+\frac{k_{11}^{\gamma_{21}}(t-1)}{k_{22}^{\gamma_{21}}(t-1)}\right)\right]
$$

setting $n=\theta \alpha / 2\left(\frac{k_{11}^{\gamma 11}(t-1)}{k_{22}^{\gamma 11}(t-1)}+\frac{k_{11}^{\gamma_{21}}(t-1)}{k_{22}^{\gamma 21}(t-1)}\right)$ and $m=\theta \alpha / 2\left(\left(\frac{k_{22}(t-1)}{k_{11}(t-1)}\right)^{\gamma_{12}}+\left(\frac{k_{22}(t-1}{k_{11}(t-1)}\right)^{\gamma_{22}}\right)$ and inserting these into the condition stated by Proposition 1 and rearranging terms we get

$$
k_{11}^{1-\gamma_{11}-\gamma_{12}}(1+\Delta m)^{1-\gamma_{11}-\gamma_{12}}>\left(\frac{2 k_{12}^{1-\gamma_{11}}(1+\Delta n)^{1-\gamma_{11}}}{k_{22}^{\gamma_{22}}(1+\Delta n)^{\gamma_{22}}}-k_{22}^{1-\gamma_{11}-\gamma_{22}}\right)(1+\Delta n)^{1-\gamma_{11}-\gamma_{12}}
$$

and

$$
k_{11}^{1-\gamma_{11}-\gamma_{12}}>\left(\frac{2 k_{12}^{1-\gamma_{11}}(1+\Delta n)^{1-\gamma_{11}-\gamma_{22}}}{k_{22}^{\gamma_{22}}(1+\Delta m)^{1-\gamma_{11}-\gamma_{12}}}-\frac{\left.k_{22}{ }^{1-\gamma_{11}-\gamma_{22}}\right)(1+\Delta n)^{1-\gamma_{11}-\gamma_{12}}}{(1+\Delta m)^{1-\gamma_{11}-\gamma_{12}}}\right.
$$

yields

$$
k_{11}^{1-\gamma_{11}-\gamma_{12}}(t-1)>\left(\frac{2 k_{12}^{1-\gamma_{11}}(t-1)}{k_{22}^{\gamma_{22}}(t-1)}-k_{22}(t-1)^{1-\gamma_{11}-\gamma_{22}}\right) \psi
$$

where

$$
\psi=\frac{\left(1+\theta \alpha\left[\left(\frac{k_{22}}{k_{11}}\right)^{-\gamma_{11}}+\left(\frac{k_{22}}{k_{11}}\right)^{\gamma_{22}-1}\right]\right)^{1-\gamma_{11}-\gamma_{22}}}{\left(1+\theta \alpha\left[\left(\frac{k_{22}}{k_{11}}\right)^{-\gamma_{11}}+\left(\frac{k_{22}}{k_{11}}\right)^{-\gamma_{22}}\right]\right)^{1-\gamma_{11}-\gamma_{22}}}
$$




\title{
Documents de travail du BETA
}

\author{
2000-01 Hétérogénéité de travailleurs, dualisme et salaire d'efficience. \\ Francesco DE PALMA, janvier 2000. \\ 2000-02 An Algebraic Index Theorem for Non-smooth Economies. \\ Gaël GIRAUD, janvier 2000. \\ 2000-03 Wage Indexation, Central Bank Independence and the Cost of Disinflation. \\ Giuseppe DIANA, janvier 2000. \\ 2000-04 Une analyse cognitive du concept de « vision entrepreneuriale ». \\ Frédéric CRÉPLET, Babak MEHMANPAZIR, février 2000. \\ 2000-05 Common knowledge and consensus with noisy communication. \\ Frédéric KCESSLER, mars 2000. \\ 2000-06 Sunspots and Incomplete Markets with Real Assets. \\ Nadjette LAGUÉCIR, avril 2000. \\ 2000-07 Common Knowledge and Interactive Behaviors : A Survey. \\ Frédéric KCESSLER, mai 2000. \\ 2000-08 Knowledge and Expertise : Toward a Cognitive and Organisational Duality of the Firm. \\ Frédéric CRÉPLET, Olivier DUPOUËT, Francis KERN, Francis MUNIER, mai 2000. \\ 2000-09 Tie-breaking Rules and Informational Cascades : A Note. \\ Frédéric KGESSLER, Anthony ZIEGELMEYER, juin 2000. \\ 2000-10 SPQR : the Four Approaches to Origin-Destination Matrix Estimation for Consideration by the \\ MYSTIC Research Consortium. \\ Marc GAUDRY, juillet 2000. \\ 2000-11 SNUS-2.5, a Multimoment Analysis of Road Demand, Accidents and their Severity in \\ Germany, 1968-1989. \\ Ulrich BLUM, Marc GAUDRY, juillet 2000. \\ 2000-12 On the Inconsistency of the Ordinary Least Squares Estimator for Spatial Autoregressive \\ Processes. \\ Théophile AZOMAHOU, Agénor LAHATTE, septembre 2000. \\ 2000-13 Turning Box-Cox including Quadratic Forms in Regression. \\ Marc GAUDRY, Ulrich BLUM, Tran LIEM, septembre 2000. \\ 2000-14 Pour une approche dialogique du rôle de l'entrepreneur/managerdans l'évolution des PME : \\ I'ISO comme révélateur ... \\ Frédéric CRÉPLET, Blandine LANOUX, septembre 2000. \\ 2000-15 Diversity of innovative strategy as a source of technological performance. \\ Patrick LLERENA, Vanessa OLTRA, octobre 2000. \\ 2000-16 Can we consider the policy instruments as cyclical substitutes ?
}




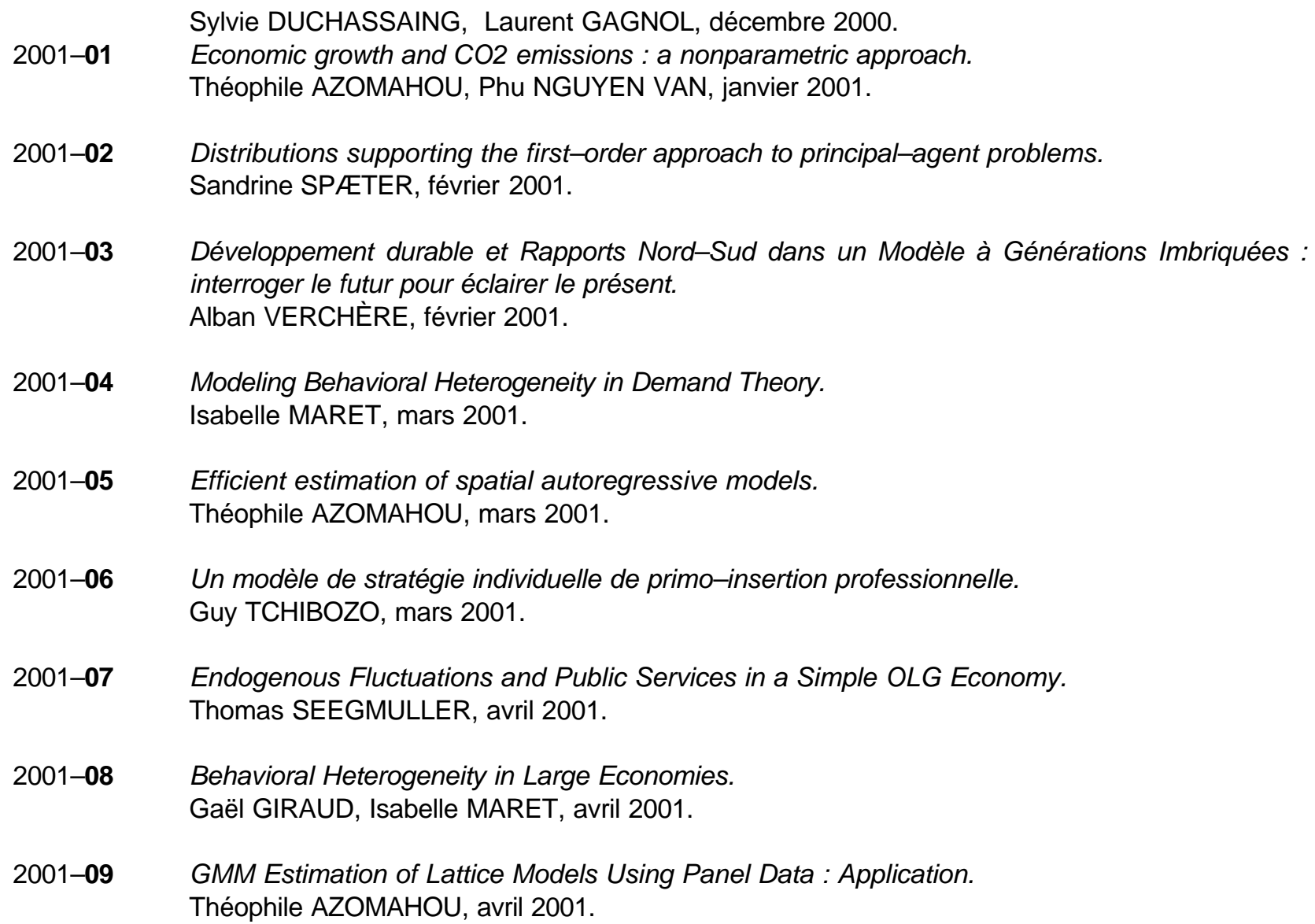

2001-10 Dépendance spatiale sur données de panel : application à la relation Brevets-R\&D au niveau régional. Jalal EL OUARDIGHI, avril 2001.

2001-11 Impact économique régional d'un pôle universitaire : application au cas strasbourgeois. Laurent GAGNOL, Jean-Alain HÉRAUD, mai 2001.

2001-12 Diversity of innovative strategy as a source of technological performance.

Patrick LLERENA, Vanessa OLTRA, mai 2001.

2001-13 La capacité d'innovation dans les regions de l'Union Européenne. Jalal EL OUARDIGHI, juin 2001.

2001-14 Persuasion Games with Higher Order Uncertainty. Frédéric KCESSLER, juin 2001.

2001-15 Analyse empirique des fonctions de production de Bosnie-Herzégovine sur la période 19521989.

Rabija SOMUN, juillet 2001.

2001-16 The Performance of German Firms in the Business-Related Service Sectors : a Dynamic Analysis.

Phu NGUYEN VAN, Ulrich KAISER, François LAISNEY, juillet 2001.

2001-17 Why Central Bank Independence is high and Wage indexation is low. Giuseppe DIANA, septembre 2001.

2001-18 Le mélange des ethnies dans les PME camerounaises: l'émergence d'un modèle d'organisation du travail. 
Raphaël NKAKLEU, octobre 2001.

2001-19 Les déterminants de la GRH des PME camerounaises.

Raphaël NK AKLEU, octobre 2001.

2001-20 Profils d'identité des dirigeants et stratégies de financement dans les PME camerounaises. Raphaël NKAKLEU, octobre 2001.

2001-21 Concurrence Imparfaite, Variabilité du Taux de Marge et Fluctuations Endogènes.

Thomas SEEGMULLER, novembre 2001.

2001-22 Determinants of Environmental and Economic Performance of Firms : An Empirical Analysis of the European Paper Industry.

Théophile AZOMAHOU, Phu NGUYEN VAN et Marcus WAGNER, novembre 2001.

2001-23 The policy mix in a monetary union under alternative policy institutions and asymmetries.

Laurent GAGNOL et Moïse SIDIROPOULOS, décembre 2001.

2001-24 Restrictions on the Autoregressive Parameters of Share Systems with Spatial Dependence. Agénor LAHATTE, décembre 2001.

2002-01 Strategic Knowledge Sharing in Bayesian Games : A General Model. Frédéric KCESSLER, janvier 2002.

2002-02 Strategic Knowledge Sharing in Bayesian Games : Applications.

Frédéric KCESSLER, janvier 2002.

2002-03 Partial Certifiability and Information Precision in a Cournot Game.

Frédéric KCESSLER, janvier 2002.

2002-04 Behavioral Heterogeneity in Large Economies.

Gaël GIRAUD, Isabelle MARET, janvier 2002.

(Version remaniée du Document de Travail n²001-08, avril 2001).

2002-05 Modeling Behavioral Heterogeneity in Demand Theory.

Isabelle MARET, janvier 2002.

(Version remaniée du Document de Travail n²001-04, mars 2001).

2002-06 Déforestation, croissance économique et population : une étude sur données de panel.

Phu NGUYEN VAN, Théophile AZOMAHOU, janvier 2002.

2002-07 Theories of behavior in principal-agent relationships with hidden action.

Claudia KESER, Marc WILLINGER, janvier 2002.

2002-08 Principe de précaution et comportements préventifs des firmes face aux risques environnementaux.

Sandrine SPÆETER, janvier 2002.

2002-09 Endogenous Population and Environmental Quality.

Phu NGUYEN VAN, janvier 2002.

2002-10 Dualité cognitive et organisationnelle de la firme au travers du concept de communauté.

Frédéric CRÉPLET, Olivier DUPOUËT, Francis KERN, Francis MUNIER, février 2002.

2002-11 Comment évaluer l'amélioration du bien-être individuel issue d'une modification de la qualité du service d'élimination des déchets ménagers?

Valentine HEINTZ, février 2002. 
2002-12 The Favorite-Longshot Bias in Sequential Parimutuel Betting with Non-Expected Utility Players.

Frédéric KCESSLER, Anthony ZIEGELMEYER, Marie-Hélène BROIHANNE, février 2002.

2002-13 La sensibilité aux conditions initiales dans les processus individuels de primo-insertion professionnelle : critère et enjeux.

Guy TCHIBOZO, février 2002.

2002-14 Improving the Prevention of Environmental Risks with Convertible Bonds.

André SCHMITT, Sandrine SPFETER, mai 2002.

2002-15 L'altruisme intergénérationnel comme fondement commun de la courbe environnementale à la Kuznets et du développement durable.

Alban VERCHÈRE, mai 2002.

2002-16 Aléa moral et politiques d'audit optimales dans le cadre de la pollution d'origine agricole de l'eau.

Sandrine SPÆETER, Alban VERCHÈRE, juin 2002.

2002-17 Parimutuel Betting under Asymmetric Information.

Frédéric KCESSLER, Anthony ZIEGELMEYER, juin 2002.

2002-18 Pollution as a source of endogenous fluctuations and periodic welfare inequality in OLG economies.

Thomas SEEGMULLER, Alban VERCHÈRE, juin 2002.

2002-19 La demande de grosses coupures et l'économie souterraine.

Gilbert KCENIG, juillet 2002.

2002-20 Efficiency of Nonpoint Source Pollution Instruments with Externality Among Polluters : An Experimental Study.

François COCHARD, Marc WILLINGER, Anastasios XEPAPADEAS, juillet 2002.

2002-21 Taille optimale dans l'industrie du séchage du bois et avantage compétitif du bois-énergie : une modélisation microéconomique.

Alexandre SOKIC, octobre 2002.

2002-22 Modelling Behavioral Heterogeneity.

Gaël GIRAUD, Isabelle MARET, novembre 2002.

2002-23 Le changement organisationnel en PME : quels acteurs pour quels apprentissages ?

Blandine LANOUX, novembre 2002.

2002-24 TECHNOLOGY POLICY AND COOPERATION : An analytical framework for a paradigmatic approach.

Patrick LLERENA, Mireille MATT, novembre 2002.

2003-01 Peut-on parler de délégation dans les PME camerounaises ?

Raphaël NKAKLEU, mars 2003.

2003-02 L'identité organisationnelle et création du capital social : la tontine d'entreprise comme facteur déclenchant dans le contexte africain.

Raphaël NKAKLEU, avril 2003.

2003-03 A semiparametric analysis of determinants of protected area.

Phu NGUYEN VAN, avril 2003. 
2003-04 Strategic Market Games with a Finite Horizon and Incomplete Markets. Gaël GIRAUD et Sonia WEYERS, avril 2003.

2003-05 Exact Homothetic or Cobb-Douglas Behavior Through Aggregation.

Gaël GIRAUD et John K.-H. QUAH, juin 2003.

2003-06 Relativité de la satisfaction dans la vie : une étude sur données de panel.

Théophile AZOMAHOU, Phu NGUYEN VAN, Thi Kim Cuong PHAM, juin 2003.

2003-07 A model of the anchoring effect in dichotomous choice valuation with follow-up. Sandra LECHNER, Anne ROZAN, François LAISNEY, juillet 2003.

2003-08 Central Bank Independence, Speed of Disinflation and the Sacrifice Ratio.

Giuseppe DIANA, Moïse SIDIROPOULOS, juillet 2003.

2003-09 Patents versus ex-post rewards : a new look.

Julien PÉNIN, juillet 2003.

2003-10 Endogenous Spillovers under Cournot Rivalry and Co-opetitive Behaviors.

Isabelle MARET, août 2003.

2003-11 Les propriétés incitatives de l'effet Saint Matthieu dans la compétition académique.

Nicolas CARAYOL, septembre 2003.

2003-12 The 'probleme of problem choice': A model of sequential knowledge production within scientific communities.

Nicolas CARAYOL, Jean-Michel DALLE, septembre 2003.

2003-13 Distribution Dynamics of $\mathrm{CO}_{2}$ Emissions.

Phu NGUYEN VAN, décembre 2003.

2004-01 Utilité relative, politique publique et croissance économique.

Thi Kim Cuong PHAM, janvier 2004.

2004-02 Le management des grands projets de haute technologie vu au travers de la coordination des compétences.

Christophe BELLEVAL, janvier 2004.

2004-03 Pour une approche dialogique du rôle de l'entrepreneur/manager dans l'évolution des PME : I'ISO comme révélateur ...

Frédéric CRÉPLET, Blandine LANOUX, février 2004.

2004-04 Consistent Collusion-Proofness and Correlation in Exchange Economies.

Gaël GIRAUD, Céline ROCHON, février 2004.

2004-05 Generic Efficiency and Collusion-Proofness in Exchange Economies.

Gaël GIRAUD, Céline ROCHON, février 2004.

2004-06 Dualité cognitive et organisationnelle de la firme fondée sur les interactions entre les communautés épistémiques et les communautés de pratique..

Frédéric CRÉPLET, Olivier DUPOUËT, Francis KERN, Francis MUNIER, février 2004.

2004-07 Les Portails d'entreprise: une réponse aux dimensions de l'entreprise "processeur de connaissances ».

Frédéric CRÉPLET, février 2004. 
2004-08 Cumulative Causation and Evolutionary Micro-Founded Technical Change : A Growth Model with Integrated Economies.

Patrick LLERENA, André LORENTZ, février 2004.

2004-09 Les CIFRE : un outil de médiation entre les laboratoires de recherche universitaire et les entreprises.

Rachel LÉVY, avril 2004.

2004-10 On Taxation Pass-Through for a Monopoly Firm.

Rabah AMIR, Isabelle MARET, Michael TROGE, mai 2004.

2004-11 Wealth distribution, endogenous fiscal policy and growth : status-seeking implications.

Thi Kim Cuong PHAM, juin 2004.

2004-12 Semiparametric Analysis of the Regional Convergence Process.

Théophile AZOMAHOU, Jalal EL OUARDIGHI, Phu NGUYEN VAN, Thi Kim Cuong PHAM, Juillet 2004.

2004-13 Les hypothèses de rationalité de l'économie évolutionniste.

Morad DIANI, septembre 2004.

2004-14 Insurance and Financial Hedging of Oil Pollution Risks.

André SCHMITT, Sandrine SPAETER, septembre 2004.

2004-15 Altruisme intergénérationnel, développement durable et équité intergénérationnelle en présence d'agents hétérogènes.

Alban VERCHÈRE, octobre 2004.

2004-16 Du paradoxe libéral-parétien à un concept de métaclassement des préférences.

Herrade IGERSHEIM, novembre 2004.

2004-17 Why do Academic Scientists Engage in Interdisciplinary Research ?

Nicolas CARAYOL, Thuc Uyen NGUYEN THI, décembre 2004.

2005-01 Les collaborations Université Entreprises dans une perspective organisationnelle et cognitive.

Frédéric CRÉPLET, Francis KERN, Véronique SCHAEFFER, janvier 2005.

2005-02 The Exact Insensitivity of Market Budget Shares and the 'Balancing Effect'.

Gaël GIRAUD, Isabelle MARET, janvier 2005.

2005-03 Les modèles de type Mundell-Fleming revisités.

Gilbert KOENIG, janvier 2005.

2005-04 L'État et la cellule familiale sont-ils substituables dans la prise en charge du chômage en Europe ? Une comparaison basée sur le panel européen.

Olivia ECKERT-JAFFE, Isabelle TERRAZ, mars 2005.

2005-05 Environment in an Overlapping Generations Economy with Endogenous Labor Supply : a Dynamic Analysis.

Thomas SEEGMULLER, Alban VERCHÈRE, mars 2005.

2005-06 Is Monetary Union Necessarily Counterproductive?

Giuseppe DIANA, Blandine ZIMMER, mars 2005.

2005-07 Factors Affecting University-Industry R\&D Collaboration : The importance of screening and signalling.

Roberto FONTANA, Aldo GEUNA, Mireille MATT, avril 2005. 
2005-08 Madison-Strasbourg, une analyse comparative de l'enseignement supérieur et de la recherche en France et aux États-Unis à travers l'exemple de deux campus.

Laurent BUISSON, mai 2005.

2005-09 Coordination des négociations salariales en UEM : un rôle majeur pour la BCE.

Blandine ZIMMER, mai 2005.

2005-10 Open knowledge disclosure, incomplete information and collective innovations.

Julien PÉNIN, mai 2005.

2005-11 Science-Technology-Industry Links and the 'European Paradox' : Some Notes on the Dynamics of Scientific and Technological Research in Europe.

Giovanni DOSI, Patrick LLERENA, Mauro SYLOS LABINI, juillet 2005.

2005-12 Hedging Strategies and the Financing of the 1992 International Oil Pollution Compensation Fund.

André SCHMITT, Sandrine SPAETER, novembre 2005.

2005-13 Faire émerger la coopération internationale: une approche expérimentale comparée du bilatéralisme et du multilatéralisme.

Stéphane BERTRAND, Kene BOUN MY, Alban VERCHÈRE, novembre 2005.

2005-14 Segregation in Networks.

Giorgio FAGIOLO, Marco VALENTE, Nicolaas J. VRIEND, décembre 2005.

2006-01 Demand and Technology Determinants of Structural Change and Tertiarisation : An InputOutput Structural Decomposition Analysis for four OECD Countries.

Maria SAVONA, André LORENTZ, janvier 2006.

2006-02 A strategic model of complex networks formation.

Nicolas CARAYOL, Pascale ROUX, janvier 2006.

2006-03 Coordination failures in network formation.

Nicolas CARAYOL, Pascale ROUX, Murat YILDIZOGLU, janvier 2006.

2006-04 Real Options Theory for Law Makers.

Marie OBIDZINSKI, Bruno DEFFAINS, janvier 2006.

2006-05 Ressources, compétences et stratégie de la firme: Une discussion de l'opposition entre la vision Porterienne et la vision fondée sur les compétences.

Fernand AMESSE, Arman AVADIKYAN, Patrick COHENDET, janvier 2006.

2006-06 Knowledge Integration and Network Formation.

Müge OZMAN, janvier 2006.

La présente liste ne comprend que les Documents de Travail publiés à partir du fer janvier 2000. La liste complète peut être donnée sur demande.

This list contains the Working Paper writen after January 2000, 1rst. The complet list is available upon request. 